\title{
Care Giver Competency in Prevention Risk of Diabetic Foot Ulcer in Diabetes Mellitus Patients
}

\author{
Kharisma Pratamaa), Jaka Pradika, Gusti Jhoni Putra, Cau Kim Jiu, Wuriani, \\ Usman, and Yenni Lukita
}

\author{
Lecturers of Sekolah Tinggi IImu Keperawatan Muhammadiyah Pontianak, Indonesia \\ a)Corresponding Author: kharisma@stikmuhptk.ac.id
}

\begin{abstract}
Increasing in the incidence of diabetic foot ulcer (DFU) among diabetes mellitus patients (DM), which then access to health services is so far, as well as the lack of knowledge of the local community in preventing and caring for DFU made researchers try to initiate training related to prevention and basic wound care for village health cadres, community leaders, and families family members with DM and at risk for UKD. The activity, which carried out in March 2021, involved the puskesmas in Sui District. Raya, Kab. Kubu Raya. After obtained a permit to carry out activities, the Team briefly contacted the community with the assistance of the Head of RT and RW. Participants who toke part in this activity were those who lived or have a family with diabetes mellitus. Participants were given training related to prevention and treatment of basic wounds, which in the end evaluation followed by publication.
\end{abstract}

Keywords: Care Giver Competency, Diabetic Foot Ulcer, Diabic Foot Care

\section{INTRODUCTION}

Foot ulceration or diabetic foot ulcer (DFU) is one of the serious complications of diabetes mellitus (DM) (Pratama and Phutthikhamin, 2017). The prevalence of DFU in Indonesia is around $15 \%$ and the incidence in DM patients is 29 times (Tri Hastuti, 2008). Based on medical record data at the West Kalimantan Provincial Hospital in 2011, there were 186 DM patients living with DFU. DFU affects quality of life, and increases morbidity and mortality, also causing a great economic burden for patients, their families, and society(Assaad-Khalil et al., 2015). Foot problems account for up to $15 \%$ of health care resources in developed countries and $40 \%$ in developing countries (Deribe, Woldemichael, \& Nemera, 2014). Many studies have shown a 1546-fold higher risk of lower limb amputation (ALL) in DM patients than the general population (Nehring et al., 2014). In addition, amputation increases the risk of ALL and patient mortality, mortality in the first month after ALL is $8.5 \%$ of patients, and over a five-year period it reaches 39-68\% (Nehring et al., 2014).

Certified nurses in diabetic foot care are involved in the early stages of care and intervention (Azizi, 2008). The nurse's role in diabetic foot care includes diabetic foot examination, wound care (Seaman, 2005), advice on appropriate foot care, and regular followup to the DM clinic (Bielby, 2006). Significantly, assessment is the first step to detect the risk of DFU, and foot care interventions should be planned to reduce ulcer risk according to the identification of risk factors (Frykberg \& Banks, 2016).

Empirically in Pontianak-West Kalimantan, five DM patients died from sepsis from DFU, and there were also several DM patients experiencing recurrent DFU. This is relevant to the nurse's statement that there are DM patients who come to the hospital with relapsed DFU. Furthermore, from the results of interviews with three nurses who work in the Pontianak Provincial Hospital, West Kalimantan, it is estimated that around 10-15 DM patients are treated in the unit every month. Data from medical records at the Kitamura Wound Care Polyclinic, Pontianak, West Kalimantan, also showed that during January-May 2015 as many as 359 DM patients suffered from DFU. The nurse said that DM patients suffering from DFU require a long treatment time for the wound healing process and will incur the cost of the wound; patients need to spend around 15-23 USD per visit. In addition, routine care is the lack of handling the occurrence of DFU among DM patients. 
There are several studies on the prevention of DFU, namely: a systematic review of the prevention of foot ulcers in at-risk DM patients (Van Netten et al., 2016), beneficial effects of foot care in patients with diabetes mellitus (Fujiwara et al., 2011), practical guidelines for its management. and prevention of diabetic foot (Bakker, Apelqvist, Schaper, \& Board, 2012), Guidelines for the Prevention of Diabetic Foot Ulcers in Patients with Diabetes Mellitus in Pontianak, West Kalimantan, Indonesia (Pratama \& Phutthikhamin, 2017). Prevention of the risk of ulceration is very important because it helps DM patients to improve their quality of life and protects them from other complications. This activity aims to determine the competence of care givers in performing foot care in DM patients.

\section{METHOD}

Sungai Ambangah is one of the villages in Sungai Raya sub-district, Kubu Raya district that needs more attention regarding the prevention of UKD. It was reported that in 2016 there were two residents who died from sepsis from diabetic foot infections or ulcers and there were approximately 60 residents who had DM. Access that is far from health services is also the cause of delays in handling UKD prevention and treatment as well as the lack of community knowledge about proper care in detecting the occurrence of UKD in family members. Providing training related to diabetic foot care to care givers or caring families is a solution in improving the quality of life of DM clients.

The activity, which will be carried out in March 2021, will involve health centers in Sungai Raya District of Kubu Raya Region. After obtaining a permit for the implementation of the activity, the team briefly contact the community which helped by village apparatus. Basically, not only those with DM who follow this program, but healthy people will also be included as secondary targets who can later be used as cadres in follow-up activities.

Participants who attend, had been given training related to prevention and treatment of basic wounds, which will eventually be evaluated followed by publication.

\section{RESULTS}

The activity was attended by 40 participants as care givers for their families who have diabetes mellitus. The training provided can be absorbed by the participants and has the potential to be applied directly to families. Demographic data and participants' abilities related to competence in preventing complications of diabetic foot wounds in the form of foot care can be seen in the following table.

Table 1. Demographic Data of Care Giver $(n=40)$

\begin{tabular}{lcc}
\hline & $\mathrm{n}(127)$ & Md Range SD \\
\hline Male & 30 & \\
\hline Female & 10 & \\
\hline Junior High School & 15 & \\
\hline $\begin{array}{l}\text { Senior High School } \\
\text { Experience of taking care } \\
\text { patients }\end{array}$ & 25 & \\
\hline
\end{tabular}

Table-1 showed that the care giver is dominated by male gender with an average high school education, as well as the length of care for the patient for 6 years.

Table 2. Care Giver Performance in diabetic foot care

\begin{tabular}{ccccc}
\hline \multirow{2}{*}{ Grade } & \multicolumn{2}{c}{ Score } & \multicolumn{2}{c}{$\begin{array}{c}\text { Total } \\
(\mathbf{n = 4 0 )}\end{array}$} \\
\cline { 2 - 5 } & $\begin{array}{c}\text { Poi } \\
\mathbf{n}\end{array}$ & $\%$ & $\mathbf{n}$ & $\%$ \\
\hline Good & $15-$ & $>75$ & 25 & 41.7 \\
& 20 & & &
\end{tabular}




\begin{tabular}{ccccc}
\hline Satisfy & $\begin{array}{c}10- \\
40\end{array}$ & $50-70$ & 10 & 48.82 \\
& & & \\
\hline Poor & $<9$ & $<45$ & 5 & 9.45 \\
\hline
\end{tabular}

Table 2 shows that 35 out of 40 respondents were able to apply foot care according to what was taught.

\section{DISCUSSION}

At the beginning of the activity, participants were given exposure related to basic knowledge of care for patients with diabetes mellitus. Participants are taught starting from the understanding of diabetes mellitus, complications to how to care so that diabetes mellitus patients do not experience complications and how to improve the quality of life of patients. When delivering the material, the participants were very enthusiastic and cooperative, so they wanted the activity to be carried out as often as possible, because they thought that this activity was to increase their knowledge about diseases that they considered hereditary. The results of the activity show that most of the care givers who apply the guidelines have satisfactory competence. Only five participants did not show the level of satisfaction, but the five participants were given the opportunity to repeat the activity until they achieved satisfactory competence.

After participating in the foot care training for diabetic feet, the participants then practiced directly in the treatment and prevention of wound complications in their families with DM. Participants are provided with a booklet containing steps in diabetic foot care.

\section{CONCLUSIONS AND RECOMMENDATIONS}

All participants have received a presentation about diabetic foot care, which can then be concluded that a number of output targets that have been achieved include: (1) active participants during the implementation of activities, (2) Organizers and partners actively cooperate. (3) participants are able to understand and demonstrate how to prevent UKD correctly, and have a strong desire to directly apply the knowledge gained. So that this activity continues to be carried out for all people in the stronghold, given the many cases of complications and amputations caused by the severity of the UKD.

\section{ACKNOWLEDGMENTS}

The author expresses his highest gratitude to STIK Muhammadiyah Pontianak which has provided support for the implementation of this activity through the Institute for Research, Community Service and Innovation (LP3MI). In addition, awards were given to PKM partners, namely Sungai Ambangah Village.

\section{REFERENCES}

Assaad-Khalil, S. H., Zaki, A., Rehim, A. A., Megallaa, M. H., Gaber, N., Gamal, H., \& Rohoma, K. H. (2015). Prevalence of diabetic foot disorders and related risk factors among Egyptian subjects with diabetes. Primary Care Diabetes, 9(4), 297-303.

Azizi, F. (2008). Beginning of the course "foot care nurse", a promise for diabetic foot prevention and care. Iranian Journal of Endocrinology and Metabolism, 10(4), 297-298.

Bakker, K., Apelqvist, J., Schaper, N. C., \& Board, I. W. G. on the D. F. E. (2012). Practical guidelines on the management and prevention of the diabetic foot 2011. Diabetes/Metabolism Research and Reviews, 28, 225-231.

Bielby, A. (2006). Understanding foot ulceration in patients with diabetes. Nursing Standard, 20(32).

Deribe, B., Woldemichael, K., \& Nemera, G. (2014). Prevalence and factors influencing diabetic foot ulcer among diabetic patients attending Arbaminch Hospital, South Ethiopia. $J$ Diabetes Metab, 5(1), 1-7.

Frykberg, R. G., \& Banks, J. (2016). Management of diabetic foot ulcers: a review. Federal 
Practitioner, 33(2), 16.

Fujiwara, Y., Kishida, K., Terao, M., Takahara, M., Matsuhisa, M., Funahashi, T., ... Shimizu, Y. (2011). Beneficial effects of foot care nursing for people with diabetes mellitus: an uncontrolled before and after intervention study. Journal of Advanced Nursing, 67(9), 1952-1962.

Nehring, P., Mrozikiewicz-Rakowska, B., Krzyżewska, M., Sobczyk-Kopcioł, A., Płoski, R., Broda, G., \& Karnafel, W. (2014). Diabetic foot risk factors in type 2 diabetes patients: a crosssectional case control study. Journal of Diabetes \& Metabolic Disorders, 13(1), 79.

Pratama, K., \& Phutthikhamin, N. (2017). Implementation of Diabetic Foot Ulcer Prevention Program in the Provincial Hospital, Pontianak, West Borneo, Indonesia. In ASEAN/Asian Academic Society International Conference Proceeding Series.

Seaman, S. (2005). The role of the nurse specialist in the care of patients with diabetic foot ulcers.

Tri Hastuti, R. (2008). Faktor-faktor Risiko Ulkus Diabetika Pada Penderita Diabetes Mellitus (Studi Kasus di RSUD Dr. Moewardi Surakarta). PROGRAM PASCA SARJANA UNIVERSITAS DIPONEGORO.

Van Netten, J. J., Price, P. E., Lavery, L. A., Monteiro-Soares, M., Rasmussen, A., Jubiz, Y., ... (IWGDF), I. W. G. on the D. F. (2016). Prevention of foot ulcers in the at-risk patient with diabetes: a systematic review. Diabetes/Metabolism Research and Reviews, 32, 84-98. 


\section{APPENDIX}

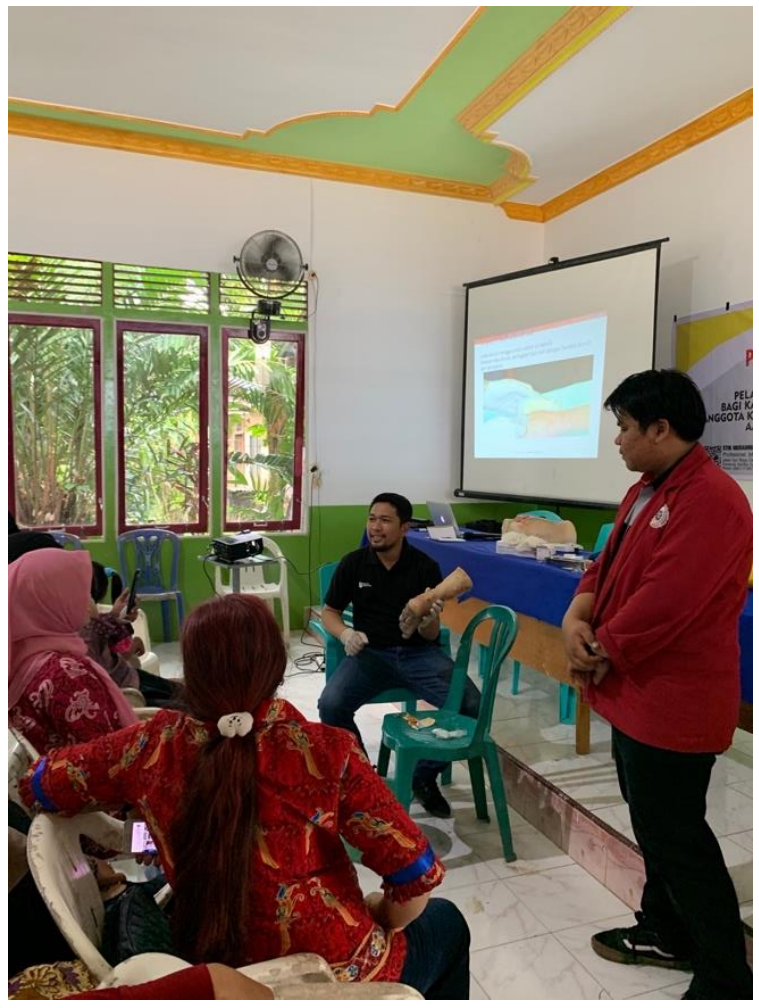

Figure 1. Demonstration of Diabetic Wound Care 